\title{
Моніторинг активності специфічного процесу в дітей із новими випадками захворювання на туберкульоз на тлі застосування імунокорегувальної терапії в комплексному лікуванні
} Разнатовська О.М., Мирончук Ю.В.

Запорізький державний медичний університет, м. Запоріжжя, Україна

Обґрунтування. Пошук нових шляхів підвищення ефективності лікування дітей із новими випадками захворювання на туберкульоз, яка залишається низькою, $\epsilon$ актуальним завданням дитячої фтизіатрії. Сучасні протоколи лікування дітей, хворих на туберкульоз, засновані на застосуванні лише антимікобактеріальної терапії (АМБТ) та не передбачають імунокорегувальної терапії імунологічних змін, які сприяють збереженню активності специфічного процесу на тлі клінічного видужання пацієнта. У більшості пацієнтів у процесі ефективного лікування досягається нормалізація основних показників імунітету, але в частини хворих розвивається вторинний імунодефіцитний стан, який зумовлює доцільність подальших досліджень, спрямованих на обґрунтування застосування імунотропних препаратів із метою стимуляції захисних сил організму, нормалізації змін імунологічного статусу та нівелювання активності специфічного процесу в дітей із новими випадками захворювання на туберкульоз. Рівень у сироватці крові неоптерину $є$ показником клітинної ланки імунітету й активності специфічного процесу.

Мета. Здійснити моніторинг активності специфічного процесу за даними рівня неоптерину в сироватці крові дітей із новими випадками захворювання на туберкульоз на тлі застосування імуномодулятора азоксимеру броміду в комплексному лікуванні.

Матеріали та методи. Рівень неоптерину в сироватці крові визначено в 51 дитини віком від 1 до 16 років із новими випадками захворювання на туберкульоз на початку інтенсивної АМБТ та після завершення основного курсу. Залежно від отриманого лікування пацієнтів було розподілено на дві групи: основна - 26 дітей, які на тлі АМБТ отримували імуномодулятор азоксимеру бромід; контрольна - 25 дітей, які отримували лише АМБТ. Рівень неоптерину в сироватці крові було також визначено в 30 здорових дітей. За віком і статтю групи були зіставні. Активність специфічного процесу вивчали шляхом дослідження рівня неоптерину в сироватці крові за допомогою методу твердофазного імуноферментного аналізу на імуноферментному рідері Sirio S із застосуванням набору IBL International Hamburg (Німеччина). Для корекції імунологічних змін із метою зниження активності специфічного процесу застосовували азоксимеру бромід (імуномодулятор): у дітей віком до 10 років внутрішньо по 6 мг двічі на добу, понад 10 років - по 12 мг двічі на добу; курс лікування - 14 діб. Результати дослідження оброблені на персональному комп'ютері з використанням

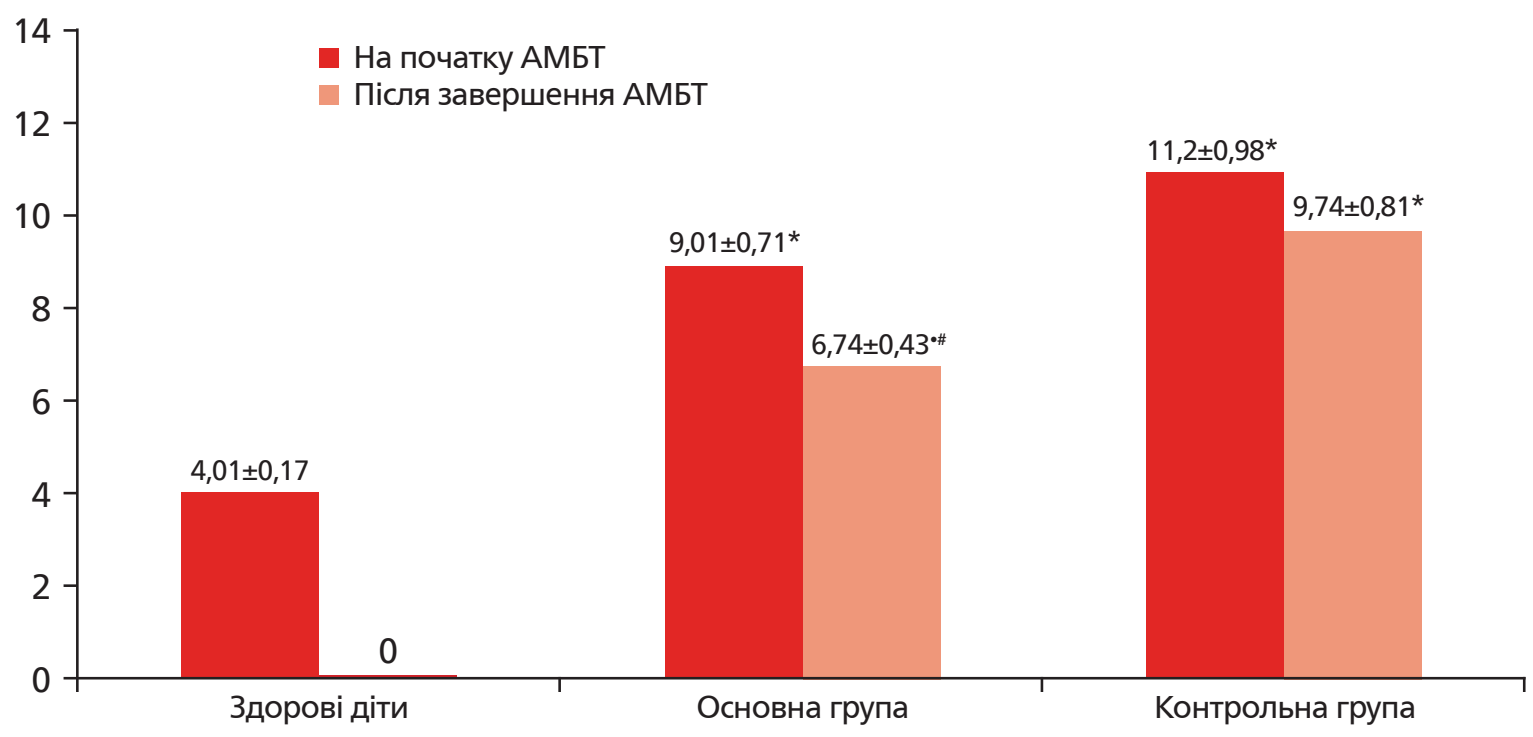

Рис. Рівень неоптерину (нмоль/л) у сироватці крові залежно від групи та фази лікування

Примітки: * - достовірна відмінність показника порівняно з таким у здорових дітей (р<0,05); •- достовірна відмінність показника в межах однієї групи на початку АМБТ і після ї̈ завершення $(p<0,05)$; \# - достовірна відмінність показника між основною та контрольною групами $(p<0,05)$. 
статистичного пакету ліцензійної програми Statistica (версія 13). Статистично значущою вважали різницю за $p<0,05$.

Результати та їх обговорення. В основній і контрольній групах на початку лікування діагностували розповсюджені форми туберкульозу, їхня частота достовірно не відрізнялася: дисемінована форма - в 6 (23,1 \%) та 7 (28 \%) пацієнтів відповідно, інфільтративна - в 11 (42,3 \%) та 4 (44 \%), первинний туберкульозний комплекс - у 9 (34,6 \%) та 7 (28 \%). Серед пацієнтів основної групи 19 (73,1 \%) отримували АМБТ чутливого туберкульозу та 7 (26,9 \%) - за ризику мультирезистентного туберкульозу (МРТБ) або МРТБ, у контрольній групі - 16 (64 \%) та 9 (36 \%) відповідно.

На початку ІФ АМБТ (рис.) рівень неоптерину був достовірно вищим порівняно з таким у здорових дітей як в основній групі (у 2,2 раза; $р<0,05)$, так і в контрольній (у 2,7 раза; $p<0,05$ ), але між групами показник достовірно не відрізнявся $(9,01 \pm 0,71$ проти $11,2 \pm 0,98 ; p<0,05)$. Після завершення ПФ АМБТ в основній групі спостерігали достовірне зниження рівня неоптерину в 1,3 раза $(p<0,05)$, що було нижче в 1,4 раза $(p<0,05)$, ніж у контрольній групі, та достовірно не відрізнялося від показника в здорових дітей.У контрольній групі рівень неоптерину залишався високим і достовірно не відрізнявся від вихідного показника на початку ІФ АМБТ.

На тлі застосування азоксимеру броміду в комплексному лікуванні дітей із новими випадками захворювання на туберкульоз тривалість АМБТ в основній групі становила 6,7士0,2 місяці, що на 1 місяць коротше, ніж

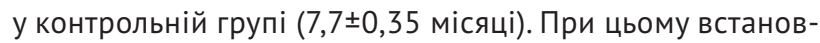
лено, що тривалість лікування нових випадків чутливого туберкульозу між групами достовірно не відрізнялася

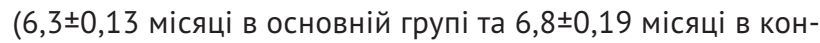
трольній групі). Проте тривалість лікування нових випадків РРТБ та МРТБ в основній групі була достовірно скорочена на 1,5 місяці порівняно з контрольною групою

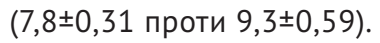

Висновки. Застосування імунокорегувальної терапії (азоксимеру броміду) в комплексному лікуванні дітей із новими випадками захворювання на туберкульоз дало змогу знизити активність специфічного процесу та майже нормалізувати рівень неоптерину, що сприяло скороченню терміну лікування на 1 місяць, а нових випадків РРТБ та МРТБ на 1,5 місяці. 